In the latter year he joined the Geological Survey of Great Britain and served on it until 1873, when he succeeded Professor Sedgwick as Woodwardian Professor of Geology at Cambridge. At first his survey work lay among the newer rocks of the south-eastern counties, but in 1866 he was transferred to the borders of the Lake District, where he did much important geological work.

"On going to Cambridge his duties as successor to the eminent Sedgwick were far from easy, but his varied attainments enabled him to discharge them with success. At the outset, in addition to the ordinary duties of his Chair, he devoted himself to three tasks which had connexion with his predecessor-namely, the adoption of the Cambrian system as defined by Sedgwick, the writing of the life of that geologist, and the erection of the Memorial Museum which has been built in his honour. The first of these would hare reopened an unfruitful controversy, and Hughes wisely discontinued it. In carrying out the second he secured the services of the late Registrar of the University-Mr. J. W. Clark-and 'The Life and Letters of Sedgwick', by Clark and Hughes, appeared in two volumes in 1890. The performance of the third task was long delayed by many disappointments and difficulties, but Hughes had the satisfaction of seeing the completion of the Sedgwick Museum, which was opened by King Edward in 1904.

"During his tenure of the professorship Hughes did much original work in geology and archæology. ${ }^{1}$ He was a fluent lecturer, but his most successful work as a teacher was due to his great capacity for arousing enthusiasm among his pupils, and many geologists owe their interest in the science to his efforts. He was elected a Fellow of the Royal Society in 1889, and received the Lyell Medal of the Geological Society in 1891, when he acknowledged the value of his intimate association with Sir Charles Lyell, with whom he made many geological tours during his early years. He was a Professorial Fellow of Clare College, and Chevalier of the Order SS. Maurice et Lazarus (Italy).

"He married, on November 28, 1882, Mary Caroline, daughter of the late Rev. G. F. Weston, Honorary Canon of Carlisle, and had three sons. Mrs. Hughes, who has herself done important geological work, was ever ready to assist her husband in the manifold duties of his professorship [see Mrs. Hughes' Memoir on the Pleistocene Mollusca of Cambridge, GEoL. MAG., 1888, p. 193].

"As Sedgwick was elected Woodwardian Professor in 1818, he and his successor have between them occupied the Chair for ninety-nine years."

\title{
LIEUT. HORAS TRISTRAM KENNEDY, B.A., F.G.S.
} BORN 1889. KILLED IN ACTION, JUNE 6, 1917.

LiEdT. Horas T. KENNEdy, F.G.S., who was killed by shell-fire south of Ypres on June 6, was a geologist of great promise on the staff of the Geological Survey of Ireland, which he joined, after open

${ }^{1}$ [For a list of his papers up to 1906 see the life of Professor Hughes, as an "Eminent Living Geologist", GEOL. MAG., 1906, pp. 10-13; the titles of ninety-three separate articles are there recorded.] 
competition, in June, 1913. He was born in London, of Irish parentage, in 1889, and gained a senior scholarship at Trinity College, Cambridge, and a first-class in the Natural Science Tripos. On entering the Survey he was employed on the revision of the Leinster Coalfield, and was looking forward to work among Silurian strata in the West of Ireland, where his undoubted powers of original research would have been called forth. War, however, broke ont, and he obtained a commission in the North Staffordshire Regiment, being transferred later to the Royal Scots Fusiliers. In the autumn of 1916 he married the second daughter of the Very Rer. C. T. Ovenden, Dean of St. Patrick's, Dublin; Mrs. Kennedy had already served for many months with a Voluntary Aid Detachment north of Etaples in France, including a winter partly spent in tents. At the close of 1916 Lieut. Kennedy was attached to the Royal Engineers for duties demanding scientific aptitude, and he was in command of a section at the time of his death. His keenness in geological work and his charm of personal manner make his loss deeply felt by his colleagues on the Survey Staff.

G. A. J. C.

\section{UPFIELD GREEN, F.G.S.}

\section{Born August 4, $1834 . \quad$ Died MaY 31, 1917.}

Oon old friend Mr. Uptield Green, who had been failing for many months, passed away suddenly at Bristol. He was born in London, educated at Brighton and Neuweid, entered the London and County Bank in 1852, became Master at Stourbridge School in 1855 , and the same year Overseer of the Wildberger Hütte. The mine stopped working in 1860, when Green returned to England and acquired the old printing business of Groom, Wilkinson \& Co. He was an enthusiastic geologist, but wrote nothing, until after thirty years' observation and study of the geology of Cornwall had given him the key to the tectonics of that county. In 1904 he published "Note on the Correlation of some Cornish Beds with the Gedinnian. of Continental Europe" (Geol. Mag., 1904); in 1909, "On the Geological Structure of Western Cornwall" (95th Rep. Roy. Geol. Soc. Cornwall), a paper which brought him the Bolitho Gold Medal; in 1912, "Note on the Pollurian-Trewavas Coast Section, Cornwall" (Geol. MAG., 1912); and in 1913, "On the General Geological Structure of Western Cornwall, with a Note on the PorthluneyDodman Section" (GEor. MAG., 1913); the last two in conjunction with C. Davies Sherborn. He had the great satisfaction of knowing that his views on this difficult and controversial area were accepted by many of his friends, especially in Belgium, France, and Germany. He was materially assisted in his researches by his personal knowledge of the structure of the North of France, Belgium, and the Rhine, and his familiarity with the fossils of the Continental Devonian rocks. He became a Member of the Geologists' Association in 1886, and a Fellow of the Geological Society in 1889 . He had held for many years a geological "At Home" once a month, when he gathered round him many friends.

C. D. S. 